\title{
Dinuclear Nickel Complexes of Thiolate-Functionalized Carbene Ligands and Their Electrochemical Properties
}

\author{
Siyuan Luo, ${ }^{\dagger}$ Maxime A. Siegler, ${ }^{\ddagger}$ and Elisabeth Bouwman ${ }^{*}{ }^{\dagger}$ (1) \\ ${ }^{\dagger}$ Leiden Institute of Chemistry, Gorlaeus Laboratories, Leiden University, P.O. Box 9502, 2300 RA Leiden, The Netherlands \\ ${ }^{\ddagger}$ Department of Chemistry, Johns Hopkins University, 3400 N. Charles Street, Baltimore, Maryland 21218, United States
}

\section{Supporting Information}

ABSTRACT: Four dimeric nickel(II) complexes $\left[\mathrm{Ni}_{2} \mathrm{Cl}_{2}\left(\mathrm{BnC}_{2} \mathrm{~S}\right)_{2}\right]$ [1], $\left[\mathrm{Ni}_{2} \mathrm{Cl}_{2}\left(\mathrm{BnC}_{3} \mathrm{~S}\right)_{2}\right][2],\left[\mathrm{Ni}_{2}\left(\mathrm{PyC}_{2} \mathrm{~S}\right)_{2}\right] \mathrm{Br}_{2}[3] \mathrm{Br}_{2}$, and $\left[\mathrm{Ni}_{2}\left(\mathrm{PyC}_{3} \mathrm{~S}\right)_{2}\right] \mathrm{Br}_{2}[4] \mathrm{Br}_{2}$ of four different thiolate-functionalized $\mathrm{N}$-heterocyclic carbene (NHC) ligands were synthesized, and their structures have been determined by single-crystal X-ray crystallography. The four ligands differ by the alkyl chain length between the thiolate group and the benzimidazole nitrogen (two $-\mathrm{C}_{2}-$ or three $-\mathrm{C}_{3}-$ carbon atoms) and the second functionality at the NHC being a benzyl (Bn) or a pyridylmethyl (Py) group. The nickel(II) ions are coordinated to the NHC carbon atom and the pendent thiolate group, which bridges to the second nickel(II) ion creating the dinuclear structure. Additionally, in compounds [1] and [2], the fourth coordination position of the square-planar $\mathrm{Ni}(\mathrm{II})$ centers is occupied by the halide ions, whereas in $[3]^{2+}$ and $[4]^{2+}$, the additional pendant

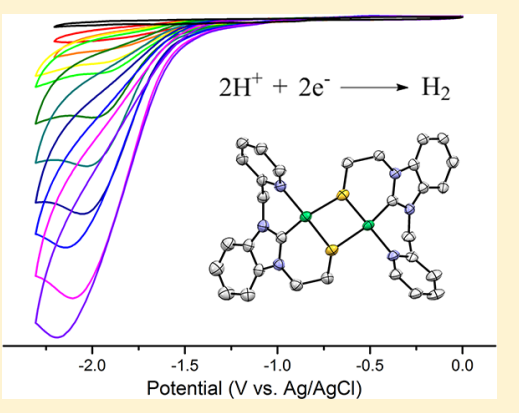
pyridylmethyl groups complete the coordination spheres of the nickel ions. The electrochemical properties of the four complexes were studied using cyclic voltammetry and controlled-potential coulometry methods. The thiolate-functionalized carbene complexes [1] and [2] appear to be poor electrocatalysts for the hydrogen evolution reaction; the complexes [3] $\mathrm{Br}_{2}$ and $[4] \mathrm{Br}_{2}$, bearing an extra pyridylmethyl group, show higher catalytic activity in proton reduction, indicating that the pyridine group plays an important role in the catalytic cycle.

\section{INTRODUCTION}

Dihydrogen is a promising fuel which can be used to meet the rapidly increasing global energy demands. It has emerged as a sustainable alternative for fossil fuel resources as upon combustion only water is generated. ${ }^{1}$ In general, platinumbased electrodes are efficient catalysts for the hydrogen evolution reaction (HER). ${ }^{2}$ However, the reserves and price of this noble metal might restrict its application in the future. Hydrogenases are enzymes that efficiently catalyze the transformation between protons and dihydrogen. ${ }^{3}$ The abundantly available, nonexpensive first row transition metals nickel and iron are present in the catalytic center of these hydrogenases. The coordination of a thiolate sulfur of cysteine to the metal ions in the active site of hydrogenases is likely to play an important role in the activity of the enzyme. Based on this knowledge, chemists worldwide focus their research efforts on mimicking the structure of the active site of hydrogenases, and either two thiolate bridges ${ }^{4-8}$ or a single thiolate bridge 9 are often incorporated in the biomimetic systems. In the search for efficient electrocatalysts for the proton reduction reaction, researchers do not limit their investigations to iron and nickel compounds but have turned their attention to cobalt, ${ }^{4}$ ruthenium, ${ }^{5}$ and manganese. ${ }^{10}$ Although these systems, such as nickel-bis(diphosphane) catalysts ${ }^{11-15}$ and cobaloximebased catalysts, ${ }^{16-19}$ do not mimic the hydrogenase active site, generally, these functional models show electrocatalytic activity better than that of the traditional structural models. ${ }^{20}$
Recently, transition metal complexes bearing pyridinefunctionalized carbene ligands have been reported as catalysts for HER. ${ }^{21-23}$ However, only a few electrochemical studies have been reported for sulfur-functionalized metal-carbene complexes. ${ }^{24}$ Herein, we report the synthesis of the dinuclear complexes $\left[\mathrm{Ni}_{2} \mathrm{Cl}_{2}\left(\mathrm{BnC}_{2} \mathrm{~S}\right)_{2}\right] \quad[\mathbf{1}], \quad\left[\mathrm{Ni}_{2} \mathrm{Cl}_{2}\left(\mathrm{BnC}_{3} \mathrm{~S}\right)_{2}\right] \quad[\mathbf{2}]$, $\left[\mathrm{Ni}_{2}\left(\mathrm{PyC}_{2} \mathrm{~S}\right)_{2}\right] \mathrm{Br}_{2}[3] \mathrm{Br}_{2}$, and $\left[\mathrm{Ni}_{2}\left(\mathrm{PyC}_{3} \mathrm{~S}\right)_{2}\right] \mathrm{Br}_{2}[4] \mathrm{Br}_{2}$ bearing four different thiolate-functionalized $\mathrm{N}$-heterocyclic carbene (NHC) ligands (Scheme 1). The thiolate group acts as a bridge between two nickel ions to form dinuclear compounds. The redox properties of these four compounds are reported as well as their electrocatalytic activity in HER.

\section{RESULTS AND DISCUSSION}

The benzimidazolium precursor salts $\left[\mathrm{HBnC}_{2} \mathrm{Br}\right] \mathrm{Br}(\mathrm{A})$ and $\left.\left[\mathrm{HBnC}_{3} \mathrm{Br}\right] \mathrm{Br}(\mathbf{B})\right)^{25}\left[\mathrm{HBnC}_{2} \mathrm{SAc}\right] \mathrm{Br}(\mathbf{C})$ and $\left[\mathrm{HBnC}_{3} \mathrm{SAc}\right] \mathrm{Br}$ (D) ${ }^{26}\left[\mathrm{HPyC}_{2} \mathrm{Br}\right] \mathrm{Br}(\mathbf{E})$ and $\left[\mathrm{HPyC}_{3} \mathrm{Br}\right] \mathrm{Br}(\mathbf{F})^{27}$ were synthesized following literature methods. The benzimidazolium salts $\left[\mathrm{HPyC}_{2} \mathrm{SAc}\right] \mathrm{Br}(\mathbf{G})$ and $\left[\mathrm{HPyC}_{3} \mathrm{SAc}\right] \mathrm{Br}(\mathbf{H})$ were synthesized based on literature methods with small modifications. ${ }^{25,26}$ The dimeric nickel compounds $\left[\mathrm{Ni}_{2} \mathrm{Cl}_{2}\left(\mathrm{BnC}_{2} \mathrm{~S}\right)_{2}\right]$ $[1], \quad\left[\mathrm{Ni}_{2} \mathrm{Cl}_{2}\left(\mathrm{BnC}_{3} \mathrm{~S}\right)_{2}\right] \quad[2], \quad\left[\mathrm{Ni}_{2}\left(\mathrm{PyC}_{2} \mathrm{~S}\right)_{2}\right] \mathrm{Br}_{2} \quad[3] \mathrm{Br}_{2}$, and $\left[\mathrm{Ni}_{2}\left(\mathrm{PyC}_{3} \mathrm{~S}\right)_{2}\right] \mathrm{Br}_{2}[4] \mathrm{Br}_{2}$ were obtained from a melt of nickel

Special Issue: Organometallic Chemistry in Europe

Received: July 28, 2017

Published: October 4, 2017 
Scheme 1. Synthesis Route of the Nickel Compounds

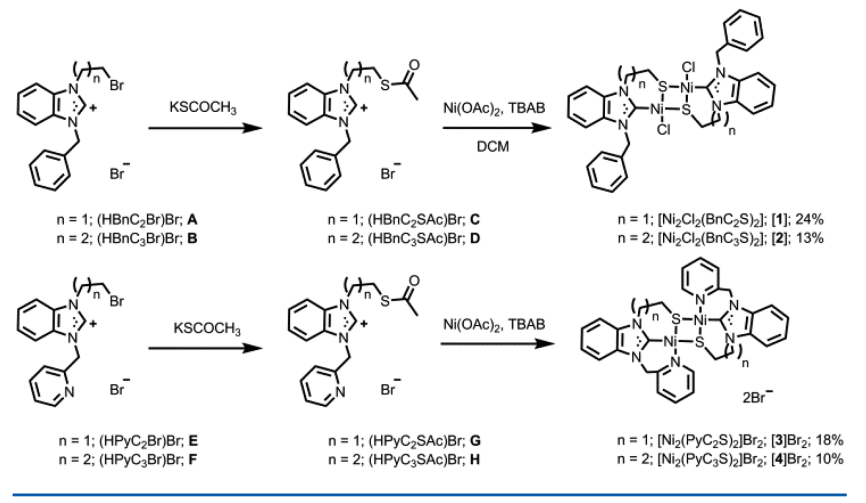

acetate with the respective acyl-protected ligand precursor (C, D, $\mathbf{G}$, and $\mathbf{H}$ ) in tetrabutylammonium bromide under vacuum at $120{ }^{\circ} \mathrm{C}$ (see Scheme 1); for these types of complexes, the procedure using a melt proved to give good results. ${ }^{28,29}$ The chloride ions in compounds $[\mathbf{1}]$ and $[2]$ are derived from the solvent dichloromethane during the recrystallization process.

Deprotonation of the benzimidazolium salt and in situ hydrolysis of the thioester group occur during the reaction with the nickel salt with the formation and evaporation of acetic acid. The four complexes were obtained as red powders. The absence of an ${ }^{1} \mathrm{H}$ NMR signal for the acidic NCHN proton (at $\sim 10 \mathrm{ppm}$ ) confirmed formation of the desired Ni-carbene bond. The low-spin state of the $\mathrm{Ni}^{\mathrm{II}}$ ions in compounds [1], [2], and $[4] \mathrm{Br}_{2}$ is evidenced by their diamagnetic ${ }^{1} \mathrm{H}$ NMR spectra. In contrast, the ${ }^{1} \mathrm{H}$ NMR spectrum of compound $[3] \mathrm{Br}_{2}$ in DMSO- $d_{6}$ shows rather broad signals (Figure S1). Low-temperature NMR spectra could not be obtained as the solvent DMSO- $d_{6}$ is not suitable. ESI-MS analysis of the four compounds shows the presence of dicationic fragment ions $[\mathrm{M}$ $-2 \mathrm{X}]^{2+}$ and $[\mathrm{M}-\mathrm{X}]^{+}$. Despite the fact that recrystallized samples of the $\mathrm{Ni}$ compounds were dried in vacuo before elemental analysis was performed, the analytical data still show the presence of the solvents that were used in recrystallization.
Single crystals of [1] and [2] suitable for X-ray diffraction were obtained from slow evaporation of dichloromethane solutions of the compounds. Solutions of the complexes [3] $\mathrm{Br}_{2}$ and $[4] \mathrm{Br}_{2}$ are not stable in air; the compounds slowly decompose as apparent from the color change (Figure S2). Single crystals of these two complexes suitable for X-ray diffraction were obtained by slow evaporation of degassed methanol solutions under a flow of argon. The crystallographic data of compounds $[1],[2],[3] \mathrm{Br}_{2}$, and $[4] \mathrm{Br}_{2}$ are collected in Table S1 in the Supporting Information; selected bonds lengths and angles are given in Table 1. Projections of the structures are shown in Figure 1.

In the structures of compounds [1] and [2], each Ni center is coordinated by the bidentate ligand via the NHC carbon atom and the thiolate sulfur of the pendant arm as well as one chloride ion; the coordination sphere of the $\mathrm{Ni}^{\mathrm{II}}$ ions is completed by a bridging thiolate donor of a second monomeric unit, resulting in the observed dinuclear structure. Thus, the coordination geometry of the nickel ions in compounds $[\mathbf{1}]$ and [2] can be described as slightly distorted square planar $\left(\tau_{4}=\right.$ $\sim 0.16$ for $[1], \tau_{4}=\sim 0.13$ for $[2] ; \tau_{4}=0$ for an ideal squareplanar geometry). ${ }^{30}$

The nickel ions in $[3] \mathrm{Br}_{2}$ and $[4] \mathrm{Br}_{2}$ are coordinated by the tridentate ligand, bound via the pyridyl nitrogen, the NHC carbon and thiolate sulfur; the coordination sphere of the nickel centers is completed by a bridging thiolate sulfur of a second nickel center, thus forming the dinuclear complexes. The square-planar geometry of the nickel centers in $[3]^{2+}$ and $[4]^{2+}$ is even less distorted than those in [1] and [2] as evidenced by the smaller $\tau_{4}$ values $\left(\tau_{4}=\sim 0.10\right.$ for $[3]^{2+}, \sim 0.07$ for $\left.[4]^{2+}\right)$.

A crystal structure of compound [1] with two bromide ions instead of chlorides has been reported in an orthorhombic symmetry with space group $P 2_{1} 2_{1} 2_{1},{ }^{31}$ whereas compound [1] crystallized in a triclinic space group. Otherwise, the environment of the nickel centers is highly similar. The bond distances and angles in [1] are comparable with those in the published structure, ${ }^{31}$ with the logical exception that the $\mathrm{Ni}-\mathrm{Cl}$ bond is shorter than the $\mathrm{Ni}-\mathrm{Br}$ distance. The complexes [2], [3] $\mathrm{Br}_{2}$, and $[4] \mathrm{Br}_{2}$ present similar $\mathrm{Ni}-\mathrm{C}$ and $\mathrm{Ni}-\mathrm{S}$ bond lengths. The

Table 1. Selected Bond Distances $(\AA)$ and Angles (deg) of Compounds [1], [2], [3] $\mathrm{Br}_{2}$, and $[4] \mathrm{Br}_{2}{ }^{a}$

\begin{tabular}{|c|c|c|c|c|}
\hline & {$[1]$} & {$[2]$} & {$[3] \mathrm{Br}_{2}$} & {$[4] \mathrm{Br}_{2}$} \\
\hline $\mathrm{Nil}-\mathrm{S}$ & $2.1736(9)$ & $2.1743(7)$ & $2.153(3)$ & $2.1829(15)$ \\
\hline Nil-S' & $2.2312(9)$ & $2.2227(6)$ & $2.227(4)$ & $2.2084(16)$ \\
\hline $\mathrm{Ni} 1-\mathrm{C}$ & $1.883(4)$ & $1.887(2)$ & $1.889(9)$ & $1.882(6)$ \\
\hline $\mathrm{Ni} 1-\mathrm{Cl} 1$ & $2.1943(9)$ & $2.2046(6)$ & & \\
\hline Nil-N & & & $1.930(8)$ & $1.922(4)$ \\
\hline $\mathrm{Ni} 1 \cdots \mathrm{Ni} 2$ & $3.0847(8)$ & $3.0413(6)$ & $2.960(4)$ & $3.068(1)$ \\
\hline $\mathrm{S}-\mathrm{Nil}-\mathrm{S}^{\prime}$ & $77.77(4)$ & $78.15(2)$ & $79.22(14)$ & $79.92(6)$ \\
\hline S-Ni1-C & $90.72(11)$ & $94.00(7)$ & $94.8(3)$ & $97.34(16)$ \\
\hline $\mathrm{S}^{\prime}-\mathrm{Ni1}-\mathrm{C}$ & $165.60(11)$ & $169.67(7)$ & $165.4(4)$ & $169.03(17)$ \\
\hline $\mathrm{S}-\mathrm{Ni1}-\mathrm{Cl}$ & $172.34(4)$ & $172.32(3)$ & & \\
\hline $\mathrm{S}^{\prime}-\mathrm{Ni} 1-\mathrm{Cl}$ & $96.03(4)$ & $96.61(2)$ & & \\
\hline $\mathrm{C}-\mathrm{Nil}-\mathrm{Cl}$ & $96.06(11)$ & $91.84(7)$ & & \\
\hline S-Nil-N & & & $163.5(3)$ & $167.46(15)$ \\
\hline $\mathrm{S}^{\prime}-\mathrm{Nil}-\mathrm{N}$ & & & 96.1(3) & $95.13(15)$ \\
\hline $\mathrm{C}-\mathrm{Nil}-\mathrm{N}$ & & & $93.2(4)$ & $89.6(2)$ \\
\hline$\alpha$ & $44.5(3)$ & $66.9(2)$ & $10.6(5)$ & $24.9(6)$ \\
\hline$\beta$ & $128.24(5)$ & $125.99(4)$ & $119.54(7)$ & $130.44(8)$ \\
\hline
\end{tabular}

${ }^{a} \mathrm{~S}=\mathrm{S} 1([\mathbf{1}]$ and $[2])$, S311 ([3] $\mathrm{Br}_{2}$ and $\left.[4] \mathrm{Br}_{2}\right) ; \mathrm{S}^{\prime}=\mathrm{S} 2$ ([1] and $\left.[2]\right), \mathrm{S} 312\left([3] \mathrm{Br}_{2}\right.$ and $\left.[4] \mathrm{Br}_{2}\right) ; \mathrm{C}=\mathrm{C} 91([1]), \mathrm{C} 101([2]), \mathrm{C} 121\left([3] \mathrm{Br}_{2}\right.$ and $\left.[4] \mathrm{Br}_{2}\right) ; \mathrm{Cl}=\mathrm{Cl} 1([\mathbf{1}]$ and $[2]) ; \mathrm{N}=\mathrm{N} 221\left([3] \mathrm{Br}_{2}\right.$ and $\left.[4] \mathrm{Br}_{2}\right)$. 


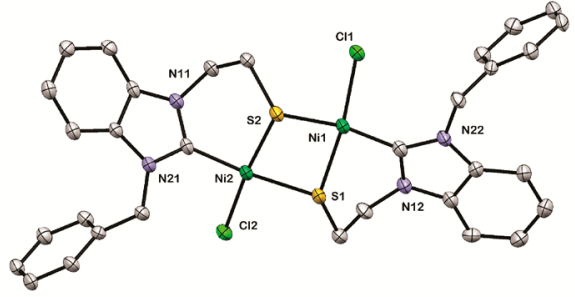

$[1]$

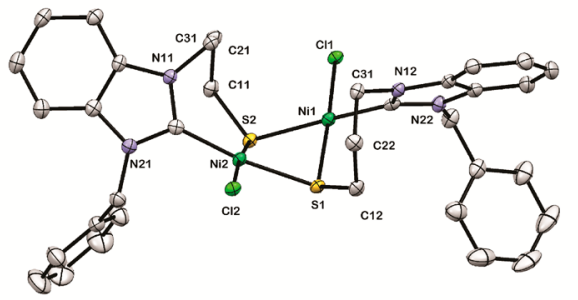

[2]

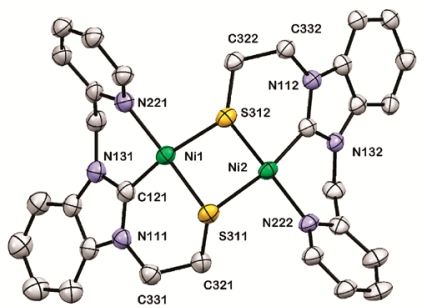

$[3]^{2+}$

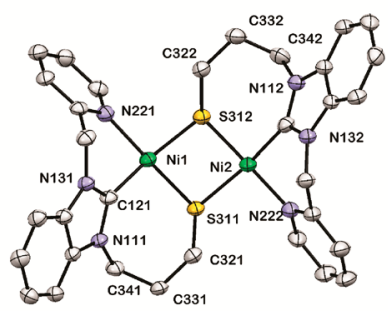

$[4]^{2+}$

Figure 1. Displacement ellipsoid plots of the cationic compounds: $[1],[2],[3]^{2+}$, and $[4]^{2+}$ drawn at the $50 \%$ probability level with selected atom numbering. Hydrogen atoms, noncoordinated bromide ions, and lattice solvent molecules are omitted for clarity.

$\mathrm{Ni}-\mathrm{C}$ bond lengths in the four complexes are all around 1.89 $\AA$, and the $\mathrm{Ni}-\mathrm{S}$ bond lengths within the chelating ligand are around 2.15-2.18 $\AA$. The $\mathrm{Ni}-\mathrm{S}$ bond distances to the thiolate sulfur of the other nickel center are slightly longer, namely, around 2.19-2.22 $\AA$. The $\mathrm{Ni}-\mathrm{N}$ bond lengths in $[3]^{2+}$ and $[4]^{2+}$ are 1.929 and $1.922 \AA$, respectively.

In order to compare the surroundings of the four complexes in detail, the dihedral angle $\alpha$ and hinge angle $\beta$ are defined (see Figure 2). The dihedral angle $\alpha$ is the torsion angle $\mathrm{N}-\mathrm{C}-\mathrm{Ni}-$
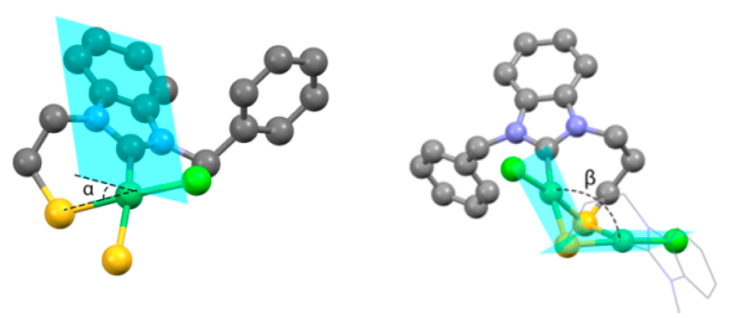

Figure 2. Schematic diagrams of the dihedral angle $\alpha$ (left, shown for compound [1]) and hinge angle $\beta$ (right, shown for compound [2]).

$S$ describing the angle between the plane of the benzimidazolidene ring and the square plane of the nickel center, indicating the orientation of the carbene ligand with respect to the plane of coordination. The hinge angle $\beta$ is the torsion angle Ni-S$\mathrm{S}^{\prime}-\mathrm{Ni}^{\prime}$, describing the dihedral angle between the two coordination planes of the adjacent nickel centers, indicating the bent nature of the dinuclear molecule. The dihedral angle $\alpha$ of the four compounds reported here follows a clear trend. In compounds [1] and [2], comprising the bidentate ligands, it is apparent that the $\mathrm{C}_{3}$ spacer between the heterocyclic ring and the thiolate donor atom offers more flexibility, allowing the $\mathrm{NHC}$ ring to orient itself in a more orthogonal position $(\alpha=$ $44^{\circ}$ for [1] vs $66^{\circ}$ for $\left.[2]\right)$. The complexes $[3] \mathrm{Br}_{2}$ and $[4] \mathrm{Br}_{2}$ show much smaller dihedral angles $\alpha$, indicating that in the tridentate ligands the presence of the third donor atom (the pendant pyridyl group) forces the NHC ring to orient itself in a more coplanar fashion with the plane of coordination. Even so, the presence of the $\mathrm{C}_{3}$ spacer in compound $[4] \mathrm{Br}_{2}$ causes a slight relaxation in the orientation of the NHC ring. In general, the NHC carbene ligand preferentially is oriented perpendicular to the plane of coordination with dihedral angles $\alpha$ close to $90^{\circ} .^{30,32-37}$ A number of exceptions have been reported for complexes bearing certain types of tridentate pincer ligands, showing dihedral angles $\alpha$ smaller than $5^{\circ}$. $^{38}$

Notably, the complex $\left[\mathrm{Ni}_{2}\left(\mathrm{PyC}_{2} \mathrm{~S}\right)_{2}\right] \mathrm{Br}_{2}[3] \mathrm{Br}_{2}$ displays not only the smallest torsion angle $\alpha\left(10.6(5)^{\circ}\right)$ but also smallest hinge angle $\beta\left(119.54(7)^{\circ}\right)$. This means that this molecule is equipped with two nearly flat "wings", but that the overall structure is significantly bent. The crystal packing of compound $[3] \mathrm{Br}_{2}$ shows an interesting interaction between one of the bromide ions with two dinuclear cations: two bent dinuclear molecules form a $\mathrm{Ni}_{4} \mathrm{~S}_{4}$ "box" encapsulating the bromide ion (see Figure 3). This bromide ion is located near the apical

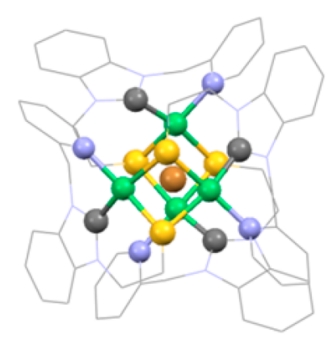

Figure 3. Projection of the interaction between two $[3]^{2+}$ cations and one bromide ion in the crystal structure of compound $[3] \mathrm{Br}_{2}$. Different elements are distinguished by color: nickel (green), sulfur (yellow), nitrogen (blue), carbon (gray), and bromide (brown).

position of each square-planar nickel center, with $\mathrm{Ni}$ to $\mathrm{Br}$ distances ranging between 3.4 and $3.6 \AA(\mathrm{Ni1} \cdots \mathrm{Br} 1=3.616(3)$ $\AA$, $\mathrm{Ni} 2 \cdots \mathrm{Br} 1=3.668(5) \AA$, $\mathrm{Ni} 3 \cdots \mathrm{Br} 1=3.422(5) \AA, \mathrm{Ni} 4 \cdots \mathrm{Br} 1=$ 3.403(6) $\AA$ ). This interaction between four Ni centers and the bromide ions holds the $\mathrm{Br}^{-}$ion in the center of a distorted " $\mathrm{Ni}_{4}$ tetrahedron". If this supramolecular interaction is retained in solution, it might be the cause of the broadening observed in the proton NMR spectrum of this compound in DMSO- $d_{6}$. Indeed, a sharper NMR spectrum is obtained using $\mathrm{CD}_{3} \mathrm{OD}$ as 
the solvent, suggesting that the protic solvent assists in the dissociation of the bromide ion by the formation of hydrogen bonds (Figure S1).

The redox properties of the two compounds $\left[\mathrm{Ni}_{2} \mathrm{Cl}_{2}\left(\mathrm{BnC}_{2} \mathrm{~S}\right)_{2}\right][\mathbf{1}]$ and $\left[\mathrm{Ni}_{2} \mathrm{Cl}_{2}\left(\mathrm{BnC}_{3} \mathrm{~S}\right)_{2}\right]$ [2] were first investigated with cyclic voltammetry $(\mathrm{CV})$ in dry $\mathrm{DMF}$ solutions containing $0.1 \mathrm{M}$ tetrabutylammonium hexafluoridophosphate $\left(\mathrm{TBAPF}_{6}\right)$ as the supporting electrolyte under a stream of argon. The CV of complex [1] shows one large irreversible reductive peak at $-1.20 \mathrm{~V}$ vs $\mathrm{Ag} / \mathrm{AgCl}$ followed by a reversible couple at $E_{1 / 2}=-1.96 \mathrm{~V}$. The reductive peak current shows a linear relationship with the scan rate, indicating a diffusion-controlled process (Figure S4). In addition, the peak-to-peak separation is $88 \mathrm{mV}$ at a scan rate of $0.1 \mathrm{~V} / \mathrm{s}$, indicating a one-electron transfer process (the peak-to-peak separation for the reference compound $\mathrm{Fc}^{+/ 0}$ is $95 \mathrm{mV}$ under these conditions). In between these reduction events, two smaller reduction peaks are present (Figure 4). The CV of complex [2] shows a similar irreversible reductive peak at $-1.28 \mathrm{~V}$ vs $\mathrm{Ag} / \mathrm{AgCl}$, at a slightly more negative potential than that of the $\mathrm{C}_{2}$ analogue.
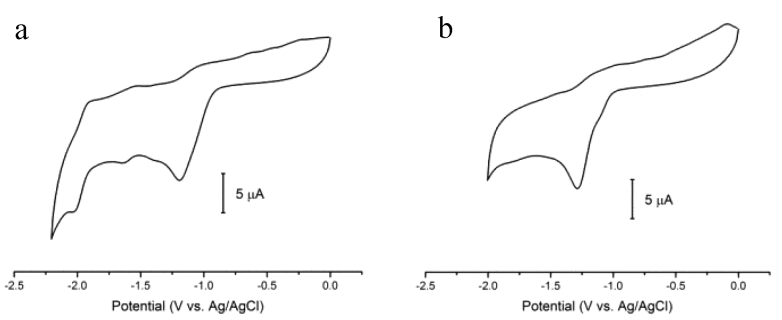

Figure 4. CVs of $1 \mathrm{mM}$ solutions in DMF of complex [1] (a) and [2] (b) recorded containing $0.1 \mathrm{M} \mathrm{TBAPF}_{6}$ as supporting electrolyte at scan rate of $0.1 \mathrm{~V} / \mathrm{s}$, using a glassy carbon working electrode.

With the aim to study the electrocatalytic activity of these compounds in HER, subsequently, acetic acid was added into the solutions of [1] and [2]. As a result, an increase in the current with an onset potential around $-1.60 \mathrm{~V}$ appeared, but in both experiments, only weak catalytic currents were observed (Figure 5).

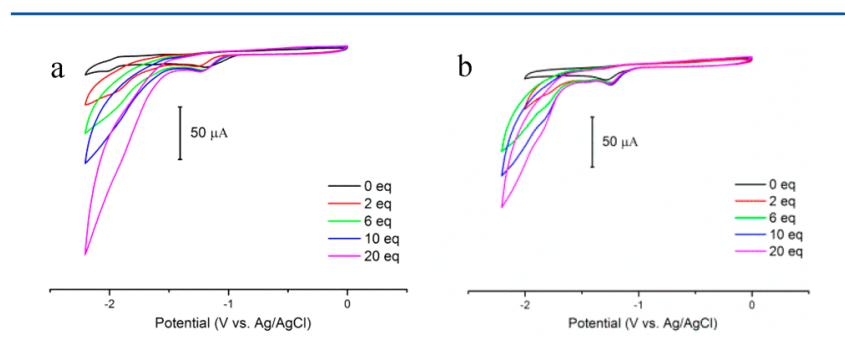

Figure 5. CVs of complexes [1] (a) and [2] (b) recorded in the presence of various equivalents of acetic acid. Solutions of $1 \mathrm{mM}$ complex in DMF containing 0.1 $\mathrm{M} \mathrm{TBAPF}_{6}$ as supporting electrolyte at a scan rate of $0.1 \mathrm{~V} / \mathrm{s}$, with glassy carbon working electrode.

The redox properties of the pyridyl-containing complexes $[3] \mathrm{Br}_{2}$ and $[4] \mathrm{Br}_{2}$ were also investigated with cyclic voltammetry. In absence of acid, complex $[3] \mathrm{Br}_{2}$ showed a number of irreversible peaks with similar current intensities in the range of -0.7 to $-1.6 \mathrm{~V}$, followed by a more or less reversible reduction at $E_{1 / 2}=-1.95 \mathrm{~V}$ vs $\mathrm{Ag} / \mathrm{AgCl}$ (Figure $\mathrm{S} 5 \mathrm{a})$. The first reductive peak at $-0.9 \mathrm{~V}$ becomes more reversible upon increasing scan rates (Figure 6a). The complex $[4] \mathrm{Br}_{2}$ with the longer alkyl chain also shows a complicated $\mathrm{CV}$
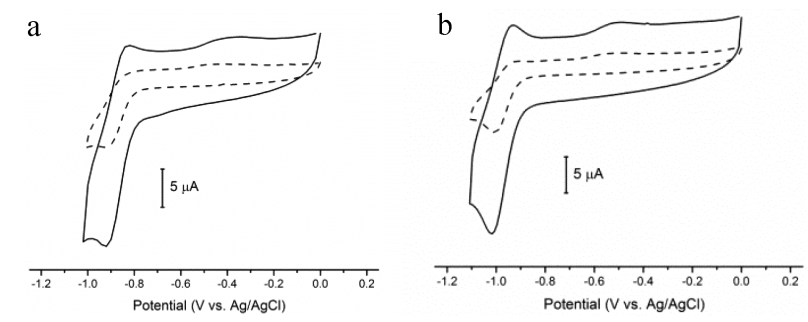

Figure 6. Cyclic voltammograms of $[3] \mathrm{Br}_{2}$ (a) and $[4] \mathrm{Br}_{2}$ (b) at different scan rates $($ dashed $=0.1 \mathrm{~V} / \mathrm{s}$; solid $=0.5 \mathrm{~V} / \mathrm{s})$. Compounds 1 $\mathrm{mM}$ in DMF containing $0.1 \mathrm{M} \mathrm{TBAPF}_{6}$ as supporting electrolyte using a glassy carbon working electrode.

(Figure S5b). Similar to complex $[3] \mathrm{Br}_{2}$, the first reductive peak becomes more reversible at higher scan rates (Figure $6 \mathrm{~b}$ ). Notably, the first redox event of $[3] \mathrm{Br}_{2}\left(E_{1 / 2}=-0.88 \mathrm{~V}\right)$ occurs at more positive potential than that of $[4] \mathrm{Br}_{2}\left(E_{1 / 2}=-0.98 \mathrm{~V}\right)$.

The complicated irreversible CVs of complex $[3] \mathrm{Br}_{2}$ and [4] $\mathrm{Br}_{2}$ might be due to solvation reactions in solution, resulting in an equilibrium of dimeric and monomeric species as shown in Figure 7. The dimeric structure might partly break up in

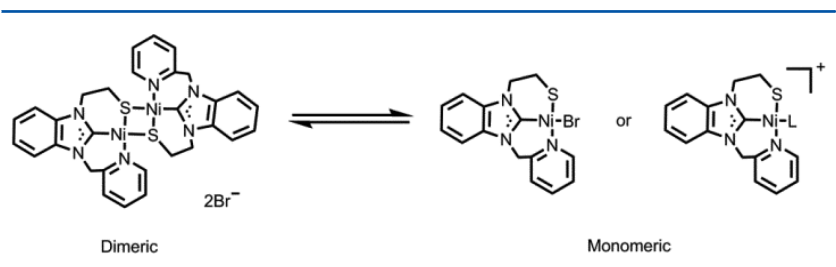

Figure 7. Proposed dimer-monomer equilibrium of $[3] \mathrm{Br}_{2}$ in solution (L = N,N-dimethylformamide).

solution after which the nickel ion coordinates with a bromide ion or solvent molecule to form monomeric compounds. The dimeric species and the different monomeric species will be reduced at different potentials, resulting in the multiple reductive waves. Alternatively, two $\mathrm{Ni}$ (II) ions in the dinuclear structure may successively be reduced to $\mathrm{Ni}(\mathrm{I})$ and then to $\mathrm{Ni}(0)$ instead of simultaneously.

Upon addition of acetic acid into the DMF solutions containing complex $[3] \mathrm{Br}_{2}$ or $[4] \mathrm{Br}_{2}$, a totally different electrochemical response is obtained compared to the complexes [1] and [2]. Whereas for complex [1] or [2] no obvious catalytic current was observed, upon addition of increasing amounts of acetic acid into the DMF solution containing complex [3] $\mathrm{Br}_{2}$, the reductive current after the onset potential of $-0.91 \mathrm{~V}$ gradually increased; a large reductive current peak is observed around $-2 \mathrm{~V}$ vs $\mathrm{Ag} / \mathrm{AgCl}$. The solution of complex $[4] \mathrm{Br}_{2}$ showed a similar result in the presence of acetic acid with an onset potential at $-1.08 \mathrm{~V}$ (Figure $8 \mathrm{~b}$ ). In both situations, with increasing concentrations of acid, the reductive current increased linearly (Figure 9). The $i_{\mathrm{c}} / i_{\mathrm{p}}$ ratio is 100 for $[3] \mathrm{Br}_{2}$ and 85 for $[4] \mathrm{Br}_{2}$ in the presence of $130 \mathrm{mM}$ acid, with $i_{\mathrm{c}}$ being the maximum current of the catalytic peak and $i_{\mathrm{p}}$ the plateau current of the noncatalytic reduction wave.

Plots of $i_{\mathrm{c}} / i_{\mathrm{p}}$ versus the square root of acid concentration for complexes $[3] \mathrm{Br}_{2}$ and $[4] \mathrm{Br}_{2}$ show a nonlinear relationship (Figure S6). Instead, a linear relationship is found between $i_{\mathrm{c}} / i_{\mathrm{p}}$ versus the acid concentration (Figure 9); thus the reaction is 

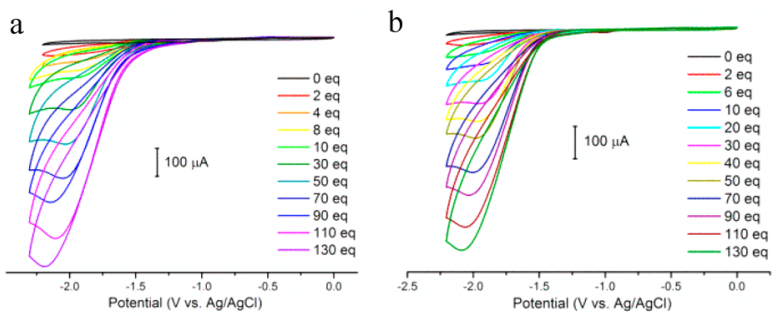

Figure 8. CVs of complexes $[3] \mathrm{Br}(\mathrm{a})$ and $[4] \mathrm{Br}(\mathrm{b})$ recorded in the presence of various amounts of acetic acid. Compounds $1 \mathrm{mM}$ in DMF containing $0.1 \mathrm{M} \mathrm{TBAPF}_{6}$ as supporting electrolyte at a scan rate of $0.1 \mathrm{~V} / \mathrm{s}$, using a glassy carbon working electrode.
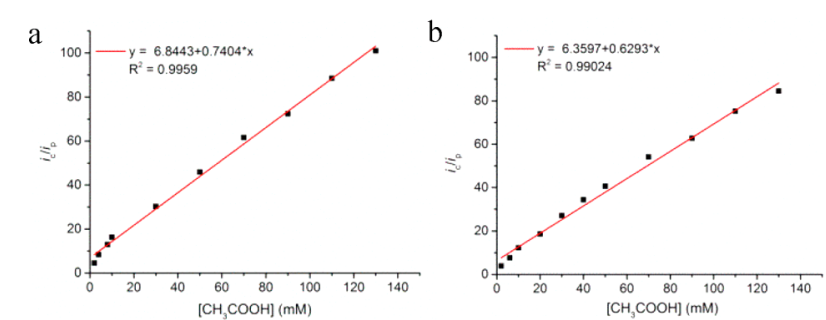

Figure 9. Plot of $i_{\mathrm{c}} / i_{\mathrm{p}}$ vs $\left[\mathrm{CH}_{3} \mathrm{COOH}\right](\mathrm{mM})$ for $[3] \mathrm{Br}_{2}(\mathrm{a})$ and [4] $\mathrm{Br}_{2}$ (b). Conditions: $1 \mathrm{mM}$ complex in DMF containing $0.1 \mathrm{M}$ $\mathrm{TBAPF}_{6}$ as supporting electrolyte at $0.1 \mathrm{~V} / \mathrm{s}$, using a glassy carbon working electrode.

second order in acid, indicating that two protons are involved in the rate-determining catalytic step. The rate constant $k_{\text {obs }}$ of the reactions cannot be calculated using eq $1^{6,12,13,41-43}$ or the foot-of-the-wave method, as the preceding reduction wave is not reversible. ${ }^{44-47}$

$$
\frac{i_{c}}{i_{p}}=\frac{n}{0.4463} \sqrt{\frac{R T k_{\mathrm{obs}}}{F v}}
$$

By comparison of the $i_{\mathrm{c}} / i_{\mathrm{p}}$ ratio, it seems that complex $[3] \mathrm{Br}_{2}$ shows higher catalytic activity in HER. However, complex [3] $\mathrm{Br}_{2}$ also presents a redox process at $E_{1 / 2}=-1.95 \mathrm{~V}$, which overlaps significantly with the catalytic current. Considering this redox event of the complex, the actual catalytic activity might be lower than expected from the $i_{\mathrm{c}} / i_{\mathrm{p}}$ ratio.

With the aim to compare the electrocatalytic activity of the four compounds in a more quantitative way, controlledpotential coulometry (CPC) experiments were carried out. The charge consumptions over time of solutions containing just the pure acid or each of the catalysts were also recorded separately as blanks. The charge accumulation graphs show that over a period of $10 \mathrm{~min}$ charge consumption is negligible for the solutions containing only acid or only the nickel compounds (Figure 10). In contrast, for solutions containing both acid and one of the nickel catalysts, continuous charge consumption was recorded. Although no clear catalytic peaks were observed in the $\mathrm{CV}$ experiments for complex [1] or [2] in the presence of acid (Figure 5), relatively high charge consumptions were observed in the CPC experiments (Figure 10b). As expected, the pyridine-functionalized compounds $[3] \mathrm{Br}_{2}$ and $[4] \mathrm{Br}_{2}$ resulted in higher charge consumptions, indicating higher catalytic activities. The quantity of dihydrogen generated during the $\mathrm{CPC}$ experiments can be estimated from the charge consumption of solutions containing both the nickel compound and the acid after subtraction of the charge consumption of the blanks; the results are listed in Table 2
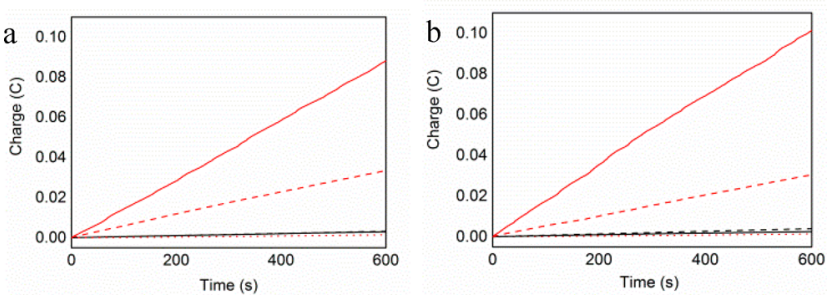

Figure 10. Charge vs time plot over $600 \mathrm{~s}$ during CPC at a potential of $-1.8 \mathrm{~V}$ on a glassy carbon working electrode. Black lines: $1 \mathrm{mM}$ solutions of the compounds in DMF in absence of acid. Red lines: 1 $\mathrm{mM}$ solutions of the compounds in DMF in the presence of $50 \mathrm{mM}$ acetic acid. Dotted red line: $50 \mathrm{mM}$ acetic acid in DMF. (a) Dashed = $\left[\mathrm{Ni}_{2} \mathrm{Cl}_{2}\left(\mathrm{BnC}_{2} \mathrm{~S}\right)_{2}\right][\mathbf{1}]$, solid $=\left[\mathrm{Ni}_{2}\left(\mathrm{PyC}_{2} \mathrm{~S}\right)_{2}\right] \mathrm{Br}_{2}[3] \mathrm{Br}_{2} ;(\mathrm{b})$ dashed $=$ $\left[\mathrm{Ni}_{2} \mathrm{Cl}_{2}\left(\mathrm{BnC}_{3} \mathrm{~S}\right)_{2}\right][2]$, solid $=\left[\mathrm{Ni}_{2}\left(\mathrm{PyC}_{3} \mathrm{~S}\right)_{2}\right] \mathrm{Br}_{2}[4] \mathrm{Br}_{2}$.

(assuming that all electrons are used in proton reduction). Among the four complexes, the compound $\left[\mathrm{Ni}_{2}\left(\mathrm{PyC}_{3} \mathrm{~S}\right)_{2}\right] \mathrm{Br}_{2}$ [4] $\mathrm{Br}_{2}$ shows the highest catalytic activity, which is estimated to produce $5 \times 10^{-4} \mathrm{mmol} \mathrm{H}_{2}$ gas in $10 \mathrm{~min}$, in the presence of 6 $\times 10^{-3} \mathrm{mmol}$ catalyst at a potential of $-1.80 \mathrm{~V}$ vs $\mathrm{Ag} / \mathrm{AgCl}$.

These compounds can hardly be considered to be good catalysts for HER; even so, it is apparent that the pyridinefunctionalized complexes $\left[\mathrm{Ni}_{2}\left(\mathrm{PyC}_{2} \mathrm{~S}\right)_{2}\right] \mathrm{Br}_{2} \quad[3] \mathrm{Br}_{2}$ and $\left[\mathrm{Ni}_{2}\left(\mathrm{PyC}_{3} \mathrm{~S}\right)_{2}\right] \mathrm{Br}_{2}[4] \mathrm{Br}_{2}$ show an activity three times higher than that of their benzyl-substituted analogues. Unfortunately, the enhancement in activity is not as dramatic as was anticipated.

\section{CONCLUSION}

In summary, the synthesis and characterization are reported for the compounds $\left[\mathrm{Ni}_{2} \mathrm{Cl}_{2}\left(\mathrm{BnC}_{2} \mathrm{~S}\right)_{2}\right][\mathbf{1}],\left[\mathrm{Ni}_{2} \mathrm{Cl}_{2}\left(\mathrm{BnC}_{3} \mathrm{~S}\right)_{2}\right]$ [2], $\left[\mathrm{Ni}_{2}\left(\mathrm{PyC}_{2} \mathrm{~S}\right)_{2}\right] \mathrm{Br}_{2}[3] \mathrm{Br}_{2}$, and $\left[\mathrm{Ni}_{2}\left(\mathrm{PyC}_{3} \mathrm{~S}\right)_{2}\right] \mathrm{Br}_{2}[4] \mathrm{Br}_{2}$, comprising four different thiolate-functionalized $\mathrm{N}$-heterocyclic carbene ligands. CV and CPC experiments were used to investigate the redox properties and electrocatalytic activity of these complexes in proton reduction. The thiolate-functionalized carbene compounds [1] and [2] show poor catalytic activity in HER. The compounds $[3] \mathrm{Br}_{2}$ and $[4] \mathrm{Br}_{2}$ were designed to include pyridine groups as potential protonaccepting sites in order to improve their electrocatalytic activity. Indeed, these compounds show catalytic activity in HER better than that of their benzyl-containing analogues, but overall, the catalytic activity remains disappointingly low. Unfortunately, the limited stability of solutions of the complexes $[3] \mathrm{Br}_{2}$ and $[4] \mathrm{Br}_{2}$ in the presence of air and the low electrocatalyic efficiency limit their potential application as proton reduction catalysts. Understanding of the role of the thiolate and pyridine groups in the catalytic cycle still requires further research, which may help in the design of efficient biomimetic catalysts for HER. Additional studies need to be undertaken to prove the occurrence of the suggested dimer-monomer equilibrium in solution in order to investigate the influence of such an equilibrium on the electrocatalytic activity.

\section{EXPERIMENTAL SECTION}

General. Commercial chemicals were used without further purification. Acetonitrile and diethyl ether were obtained from a PureSolv MD5 solvent dispenser. Dry dimethylformamide was prepared by adding molecular sieves into commercial anhydrous solvent. The other commercial solvents were used without further purification. Air-sensitive reactions were performed under argon or 
Table 2. Estimated Amount of Dihydrogen Generated by the Four Compounds in $10 \mathrm{~min}\left(n_{\text {catalyst }}=6 \times 10^{-3} \mathrm{mmol}\right)$

$\begin{array}{ccccc}\text { compound } & {\left[\mathrm{Ni}_{2} \mathrm{Cl}_{2}\left(\mathrm{BnC}_{2} \mathrm{~S}\right)_{2}\right][\mathbf{1}]} & {\left[\mathrm{Ni}_{2} \mathrm{Cl}_{2}\left(\mathrm{BnC}_{3} \mathrm{~S}\right)_{2}\right][2]} & {\left[\mathrm{Ni}_{2}\left(\mathrm{PyC}_{2} \mathrm{~S}\right)_{2}\right] \mathrm{Br}_{2}[3] \mathrm{Br}_{2}} & {\left[\mathrm{Ni}_{2}\left(\mathrm{PyC}_{3} \mathrm{~S}\right)_{2}\right] \mathrm{Br}_{2}[4] \mathrm{Br}_{2}} \\ n\left(\mathrm{H}_{2}\right)(\mathrm{mmol}) & 1.5 \times 10^{-4} & 1.5 \times 10^{-4} & 4 \times 10^{-4} & 5 \times 10^{-4}\end{array}$

dinitrogen atmosphere using standard Schlenk techniques unless mentioned otherwise.

${ }^{1} \mathrm{H}$ and ${ }^{13} \mathrm{C}$ NMR spectra were recorded on a Bruker $300 \mathrm{DPX}$ spectrometer. Mass spectra were obtained using a Finnigan Aqua mass spectrometer (MS) with electrospray ionization (ESI). UV-vis spectra were obtained using a transmission dip probe using an Avantes Avaspec-2048 spectrometer with an Avalight-DH-S-BAL light source. Elemental analyses were performed by the Kolbe Mikroanalytisches Laboratorium, Germany. Cyclic voltammetry was recorded with an Autolab PGstat10 potentiostat controlled by GPES4 software under argon. A $3 \mathrm{~mm}$ diameter glassy carbon electrode was used as working electrode and a platinum wire as the counter electrode. The cyclic voltammetry was performed in dry DMF with $0.1 \mathrm{M} \mathrm{TBAPF}_{6}$ as the supporting electrolyte under a stream of argon at room temperature. The experimental reference was a $\mathrm{Ag} / \mathrm{AgCl}(3 \mathrm{M} \mathrm{KCl})$ electrode in the electrolyte solution $\left(\mathrm{TBAPF}_{6}\right)$. Ferrocene was added at the end of each measurement as an internal standard. Under these conditions, the $\mathrm{Fc} / \mathrm{Fc}^{+}$couple was located at $0.510 \mathrm{~V}$ vs $\mathrm{Ag} / \mathrm{AgCl}$ with a $\Delta E_{\mathrm{p}}$ of 95 $\mathrm{mV}$. The surface of the working electrode was polished, sonicated, and rinsed before each single $\mathrm{CV}$ measurement. Controlled-potential coulometry experiments were carried out with an Autolab PGstat10 potentiostat controlled by GPES4 software under argon. A $3 \mathrm{~mm}$ diameter glassy carbon electrode was used as working electrode and a platinum wire as the counter electrode. The complex $(0.006 \mathrm{mmol})$ and acetic acid $(17.5 \mu \mathrm{L})$ were added into $6 \mathrm{~mL}$ of dry degassed DMF with $0.1 \mathrm{M} \mathrm{TBAPF}_{6}$ as the supporting electrolyte under a stream of argon at room temperature, thus forming a solution $1 \mathrm{mM}$ in catalyst and $50 \mathrm{mM}$ in acid. A CPC experiment was run at $-1.8 \mathrm{~V}$ for $600 \mathrm{~s}$, whereas the solution was stirred continuously. The blank and reference CPC experiments (only acid or only catalyst added) were performed using the same conditions. Each independent CPC experiment was performed two times. The charge consumption used to calculate the $\mathrm{H}_{2}$ production was the average of two experiments. The electrode was polished between each single measurement, and charge consumption was not observed when the electrode was used without polishing in a new solution containing acid but in the absence of fresh catalyst.

Single-crystal X-ray crystallography details and refinement data are given in the Supporting Information. All reflection intensities were measured at $110(2) \mathrm{K}$ using a SuperNova diffractometer (equipped with Atlas detector) with $\mathrm{Cu} \mathrm{K} \alpha$ radiation $(\lambda=1.54178 \AA$ ) under the program CrysAlisPro (versions 1.171.36.32, 1.171.37.31, or 1.171.37.35 Agilent Technologies, 2013-2014). The same program was used to refine the cell dimensions and for data reduction. The structure was solved with the program SHELXS-2013 ${ }^{48}$ and was refined on $F^{2}$ with SHELXL-2013. ${ }^{48}$ Analytical numeric absorption corrections based on a multifaceted crystal model were applied using CrysAlisPro. The temperature of the data collection was controlled using the system Cryojet (manufactured by Oxford Instruments). The $\mathrm{H}$ atoms were placed at calculated positions (unless otherwise specified) using the instructions of AFIX 23, AFIX 43, AFIX 137, or AFIX 147 with isotropic displacement parameters having values of 1.2 or $1.5 U_{\text {eq }}$ of the attached $\mathrm{C}$ atoms. For $[4] \mathrm{Br}_{2}$, the $\mathrm{H}$ atoms attached to O1W were found from difference Fourier maps, and their coordinates were refined freely.

Synthesis of Ligand Precursors. N-Pyridylmethylbenzimidazole $^{49}$ and the benzimidazolium ligand precursor salts $\left[\mathrm{HBnC}_{2} \mathrm{Br}\right] \mathrm{Br}$ (A) and $\left[\mathrm{HBnC}_{3} \mathrm{Br}\right] \mathrm{Br}(\mathbf{B}),{ }^{25}\left[\mathrm{HBnC}_{2} \mathrm{SAc}\right] \mathrm{Br}(\mathbf{C}),\left[\mathrm{HBnC}_{3} \mathrm{SAc}\right] \mathrm{Br}$ (D), ${ }^{26}\left[\mathrm{HPyC}_{2} \mathrm{Br}\right] \mathrm{Br}(\mathrm{E})$, and $\left[\mathrm{HPyC}_{3} \mathrm{Br}\right] \mathrm{Br}(\mathbf{F})^{27}$ were synthesized following literature methods.

[HPyC $\left.{ }_{2} \mathrm{SAC}\right] \mathrm{Br}(\mathrm{G}):$ A mixture of salt $\mathrm{E}(0.625 \mathrm{~g}, 1.6 \mathrm{mmol})$ and $\mathrm{KSCOCH}_{3}(0.200 \mathrm{~g}, 1.8 \mathrm{mmol})$ in acetonitrile $(10 \mathrm{~mL})$ was stirred at room temperature for $16 \mathrm{~h}$. The suspension was filtered, yielding a white powder. The white powder was washed with diethyl ether to get the pure product in a yield of $0.44 \mathrm{~g}(72 \%) .{ }^{1} \mathrm{H}$ NMR $(300 \mathrm{MHz}$, DMSO- $\left.d_{6}\right) \delta 10.02(\mathrm{~s}, 1 \mathrm{H}), 8.49(\mathrm{~d}, J=4.8 \mathrm{~Hz}, 1 \mathrm{H}), 8.17$ (d, $J=8.4$
$\mathrm{Hz}, 1 \mathrm{H}), 7.99-7.85(\mathrm{~m}, 2 \mathrm{H}), 7.75-7.57(\mathrm{~m}, 3 \mathrm{H}), 7.43-7.32(\mathrm{~m}, 1 \mathrm{H})$, $5.95(\mathrm{~s}, 2 \mathrm{H}), 4.77(\mathrm{t}, J=6.4 \mathrm{~Hz}, 2 \mathrm{H}), 3.43(\mathrm{t}, J=6.6 \mathrm{~Hz}, 2 \mathrm{H}), 2.28(\mathrm{~s}$, $3 \mathrm{H}) .{ }^{13} \mathrm{C}$ NMR (75 MHz, DMSO- $\left.d_{6}\right) \delta=149.63,143.30,137.57$, $126.80,126.71,123.74,122.74,113.93,113.84,50.87,46.19,30.50$, 27.83. The resonances of the four quaternary carbon atoms were not detected. ESI-MS found (calcd): $[\mathrm{M}-\mathrm{Br}]^{+} \mathrm{m} / z 312.1$ (312.1).

$\left[\mathrm{HPyC}_{3} \mathrm{SAC}\right] \mathrm{Br}(\boldsymbol{H}): \mathrm{A}$ mixture of salt $\mathbf{F}(0.500 \mathrm{~g}, 1 \mathrm{mmol})$ and $\mathrm{KSCOCH}_{3}(0.170 \mathrm{~g}, 1.2 \mathrm{mmol})$ in acetonitrile $(10 \mathrm{~mL})$ was stirred at room temperature for $48 \mathrm{~h}$. The suspension was filtered, yielding a white powder, which was washed with a mixture of the filtrate and diethyl ether. The white powder was purified by column chromatography $\left(\mathrm{Al}_{2} \mathrm{O}_{3}\right.$, dichloromethane, dichloromethane/methanol = 3:1) giving a yield of $0.37 \mathrm{~g}(75 \%) .{ }^{1} \mathrm{H}$ NMR $(300 \mathrm{MHz}$, DMSO- $\left.d_{6}\right) \delta 10.00(\mathrm{~s}, 1 \mathrm{H}), 8.48(\mathrm{~d}, J=5.6 \mathrm{~Hz}, 1 \mathrm{H}), 8.10(\mathrm{~d}, J=7.0$ $\mathrm{Hz}, 1 \mathrm{H}), 8.00-7.84(\mathrm{~m}, 2 \mathrm{H}), 7.74-7.60(\mathrm{~m}, 3 \mathrm{H}), 7.38(\mathrm{dd}, J=7.0$, $5.3 \mathrm{~Hz}, 1 \mathrm{H}), 5.92(\mathrm{~s}, 2 \mathrm{H}), 4.62(\mathrm{t}, J=7.0 \mathrm{~Hz}, 2 \mathrm{H}), 2.93(\mathrm{t}, J=7.3 \mathrm{~Hz}$, $2 \mathrm{H}), 2.32(\mathrm{~s}, 3 \mathrm{H}), 2.19$ (p, $J=7.1 \mathrm{~Hz}, 2 \mathrm{H}) .{ }^{13} \mathrm{C}$ NMR $(75 \mathrm{MHz}$, DMSO- $\left.d_{6}\right) \delta=149.57,137.54,126.77,126.63,123.72,122.75,113.89$, $113.79,50.86,45.77,28.68,25.23$. The resonances of the four quaternary carbon atoms were too weak to be detected. ESI-MS found (calcd): $[\mathrm{M}-\mathrm{Br}]^{+} \mathrm{m} / z 316.1$ (316.1).

Synthesis of the Nickel Compounds. $\left[\mathrm{Ni}_{2} \mathrm{Cl}_{2}\left(\mathrm{BnC}_{2} \mathrm{~S}\right)_{2}\right]$ [1]: Ligand precursor $\mathbf{C}(0.390 \mathrm{~g}, 1.0 \mathrm{mmol})$, anhydrous $\mathrm{Ni}(\mathrm{OAc})_{2}(0.090$ $\mathrm{g}, 0.5 \mathrm{mmol})$, and tetrabutylammonium bromide $(2 \mathrm{~g})$ were weighed into a $10 \mathrm{~mL}$ round-bottomed flask and dried for $3 \mathrm{~h}$ at $60{ }^{\circ} \mathrm{C}$ under vacuum. Then the temperature of the flask was increased to $120{ }^{\circ} \mathrm{C}$ and kept constant for $24 \mathrm{~h}$. The mixture was allowed to cool to room temperature and then was triturated with $\mathrm{H}_{2} \mathrm{O}(10 \mathrm{~mL})$ and DCM $(20$ $\mathrm{mL}$ ). The organic layer was separated, washed with brine, and dried on sodium sulfate. Removal of the solvent resulted in a red solid in a yield of $85 \mathrm{mg}(24 \%)$. Single crystals suitable for X-ray structure determination were obtained from a DCM solution of the complex. ${ }^{1} \mathrm{H}$ NMR (300 MHz, chloroform-d) $\delta 7.63(\mathrm{~d}, J=6.1 \mathrm{~Hz}, 4 \mathrm{H}), 7.47-$ $7.01(\mathrm{~m}, 14 \mathrm{H}), 6.68(\mathrm{~d}, J=15.5 \mathrm{~Hz}, 2 \mathrm{H}), 5.69(\mathrm{~d}, J=15.6 \mathrm{~Hz}, 2 \mathrm{H})$, $5.07(\mathrm{t}, J=13.0 \mathrm{~Hz}, 2 \mathrm{H}), 4.78(\mathrm{~d}, J=13.4 \mathrm{~Hz}, 2 \mathrm{H}), 2.89(\mathrm{~d}, J=12.4$ $\mathrm{Hz}, 2 \mathrm{H}), 1.36(\mathrm{t}, J=11.8 \mathrm{~Hz}, 2 \mathrm{H}) .{ }^{13} \mathrm{C}$ NMR $(75 \mathrm{MHz}$, chloroform- $d$ ) $\delta 174.30,136.45,134.95,133.94,128.95,128.10,127.97,123.28$, 123.24, 111.39, 110.07, 52.32, 49.34, 24.19. Anal. Calcd for $\mathrm{C}_{32} \mathrm{H}_{30} \mathrm{~N}_{4} \mathrm{~S}_{2} \mathrm{Ni}_{2} \mathrm{Cl}_{2} \mathrm{CH}_{2} \mathrm{Cl}_{2}$ : C, 49.06; H, 3.99; N, 6.93. Found: $\mathrm{C}$, 49.26; H, 4.17; N, 6.75. ESI-MS found (calcd): $[\mathrm{M}-2 \mathrm{Cl}]^{2+} \mathrm{m} / z$ 325.0 (325.03); $[\mathrm{M}-\mathrm{Cl}]^{+} \mathrm{m} / z 685.3$ (685.03).

$\left[\mathrm{Ni}_{2} \mathrm{Cl}_{2}\left(\mathrm{BnC}_{3} \mathrm{~S}\right)_{2}\right]$ [2]: Ligand precursor $\mathbf{D}(0.405 \mathrm{~g}, 1.0 \mathrm{mmol})$, anhydrous $\mathrm{Ni}(\mathrm{OAc})_{2}(0.177 \mathrm{~g}, 1.0 \mathrm{mmol})$, and tetrabutylammonium bromide $(2 \mathrm{~g})$ were weighed into a $10 \mathrm{~mL}$ round-bottomed flask and dried for $3 \mathrm{~h}$ at $60{ }^{\circ} \mathrm{C}$ under vacuum. Then the temperature was increased to $120{ }^{\circ} \mathrm{C}$ and kept constant for $24 \mathrm{~h}$. The mixture was allowed to cool to room temperature and then was triturated with $\mathrm{H}_{2} \mathrm{O}(10 \mathrm{~mL})$ and DCM $(20 \mathrm{~mL})$. The organic layer was separated, washed with brine, and dried on sodium sulfate. Removal of the solvent resulted in a red solid, which was washed with diethyl ether, giving a yield of $50 \mathrm{mg}$ (13\%). Single crystals suitable for X-ray structure determination were obtained from a DCM solution. ${ }^{1} \mathrm{H}$ NMR $\left(300 \mathrm{MHz}\right.$, dichloromethane- $\left.d_{2}\right) \delta 7.85(\mathrm{td}, J=13.6,5.9 \mathrm{~Hz}$, $2 \mathrm{H}), 7.55(\mathrm{~d}, J=6.8 \mathrm{~Hz}, 2 \mathrm{H}), 7.49-7.29(\mathrm{~m}, 8 \mathrm{H}), 7.25-7.07$ (m, $6 \mathrm{H}), 6.56(\mathrm{~d}, J=15.6 \mathrm{~Hz}, 2 \mathrm{H}), 5.53(\mathrm{~d}, J=15.6 \mathrm{~Hz}, 2 \mathrm{H}), 5.12(\mathrm{dd}, J=$ $14.3,6.6 \mathrm{~Hz}, 2 \mathrm{H}), 2.93(\mathrm{~m}, 2 \mathrm{H}), 2.12(\mathrm{dd}, J=13.5,4.1 \mathrm{~Hz}, 2 \mathrm{H}), 0.63$ $(\mathrm{td}, J=13.5,4.9 \mathrm{~Hz}, 2 \mathrm{H}) .{ }^{13} \mathrm{C}$ NMR $\left(75 \mathrm{MHz}\right.$, dichloromethane- $\left.d_{2}\right) \delta$ $=176.08,136.67,135.54,133.79,129.18,128.39,128.21,123.40$, 123.17, 111.40, 109.96, 51.94, 44.51, 23.84, 22.59. Anal. Calcd for $\mathrm{C}_{34} \mathrm{H}_{34} \mathrm{~N}_{4} \mathrm{~S}_{2} \mathrm{Ni}_{2} \mathrm{Cl}_{2} \mathrm{C}_{4} \mathrm{H}_{10} \mathrm{O}: \mathrm{C}, 55.31 ; \mathrm{H}, 5.37 ; \mathrm{N}, 6.79$. Found: C, 55.15; H, 5.09; N, 6.54. ESI-MS found (calcd): $[\mathrm{M}-\mathrm{Cl}]^{+} \mathrm{m} / z 713.3$ (713.06).

$\left[\mathrm{Ni}_{2}\left(\mathrm{PyC}_{2} \mathrm{~S}\right)_{2}\right] \mathrm{Br}_{2}[3] \mathrm{Br}_{2}$ : Ligand precursor $\mathbf{G}(0.380 \mathrm{~g}, 0.8 \mathrm{mmol})$, anhydrous $\mathrm{Ni}(\mathrm{OAc})_{2}(0.140 \mathrm{~g}, 0.8 \mathrm{mmol})$, and tetrabutylammonium 
bromide $(1.5 \mathrm{~g})$ were weighed into a $10 \mathrm{~mL}$ round-bottom flask and dried for $3 \mathrm{~h}$ at $80{ }^{\circ} \mathrm{C}$ under vacuum. Then the temperature was increased to $120{ }^{\circ} \mathrm{C}$ and kept for $48 \mathrm{~h}$. The mixture was allowed to cool to room temperature and then was triturated with $\mathrm{H}_{2} \mathrm{O}(10 \mathrm{~mL})$ resulting in a red solid. The solid was washed with a small amount of DCM and dried in vacuum, giving a yield of $75 \mathrm{mg}$ of a red solid (18\%). Crystals suitable for X-ray structure determination were obtained by slow evaporation of a degassed methanol solution under a flow of argon. ${ }^{1} \mathrm{H}$ NMR showed broad signals. ${ }^{1} \mathrm{H}$ NMR $(300 \mathrm{MHz}$, DMSO- $\left.d_{6}\right) \delta=9.09,8.13,8.00,7.91,7.75(\mathrm{~d}, J=7.6 \mathrm{~Hz}, 2 \mathrm{H}), 7.57$, 7.43, 6.16, 4.53, 2.13. Anal. Calcd for $\mathrm{C}_{30} \mathrm{H}_{28} \mathrm{~N}_{6} \mathrm{~S}_{2} \mathrm{Ni}_{2} \mathrm{Br}_{2} \cdot 1.5 \mathrm{H}_{2} \mathrm{O}$ : C, 42.85; H, 3.72; N, 9.99. Found: C, 42.55; H, 3.40; N, 9.99. ESI-MS found (calcd): $[\mathrm{M}-2 \mathrm{Br}]^{2+} \mathrm{m} / z$ 326.1 (326.03); $[1 / 2 \mathrm{M}-\mathrm{Br}+$ $\mathrm{MeOH}]^{+}$(mononuclear) $m / z 358.1$ (358.05).

$\left[\mathrm{Ni}_{2}\left(\mathrm{PyC}_{3} \mathrm{~S}_{2}\right] \mathrm{Br}_{2}[4] \mathrm{Br}_{2}\right.$ : Ligand precursor $\mathrm{H}(0.405 \mathrm{~g}, 1.0 \mathrm{mmol})$, anhydrous $\mathrm{Ni}(\mathrm{OAc})_{2}(0.180 \mathrm{~g}, 1.0 \mathrm{mmol})$, and tetrabutylammonium bromide $(1.9 \mathrm{~g})$ were weighed into a $10 \mathrm{~mL}$ round-bottom flask and dried for $3 \mathrm{~h}$ at $80{ }^{\circ} \mathrm{C}$ under vacuum. Then the temperature was increased to $130{ }^{\circ} \mathrm{C}$ and kept for $24 \mathrm{~h}$. The mixture was allowed to cool to room temperature and then was triturated with $\mathrm{H}_{2} \mathrm{O}(10 \mathrm{~mL})$ resulting in a red solid. The solid was washed with a small amount of DCM and dried in vacuum, giving a yield of $42 \mathrm{mg}$ (10\%). Crystals suitable for X-ray structure determination were obtained by slow evaporation of a degassed methanol solution under a flow of argon. ${ }^{1} \mathrm{H}$ NMR $\left(300 \mathrm{MHz}\right.$, DMSO- $\left.d_{6}\right) \delta 8.88(\mathrm{~d}, J=5.3 \mathrm{~Hz}, 2 \mathrm{H}), 8.09-8.00$ $(\mathrm{m}, 4 \mathrm{H}), 7.88(\mathrm{~d}, J=7.7 \mathrm{~Hz}, 2 \mathrm{H}), 7.76(\mathrm{~d}, J=8.0 \mathrm{~Hz}, 2 \mathrm{H}), 7.51-7.39$ (m, 6H), $6.58(\mathrm{~d}, J=15.4 \mathrm{~Hz}, 2 \mathrm{H}), 6.29(\mathrm{~d}, J=15.1 \mathrm{~Hz}, 2 \mathrm{H}), 4.84$ (broad, $2 \mathrm{H}), 4.67(\mathrm{~d}, J=12.8 \mathrm{~Hz}, 2 \mathrm{H}), 1.92$ (broad, $4 \mathrm{H}), 1.43$ (broad, $4 \mathrm{H}) .{ }^{13} \mathrm{C}$ NMR $\left(75 \mathrm{MHz}, \mathrm{DMSO}-d_{6}\right) \delta=171.14,154.93,154.70$, $140.08,133.51,133.33,125.47,125.29,123.76,111.31,110.96,50.25$, 42.37, 27.18, 24.53. Anal. Calcd for $\mathrm{C}_{32} \mathrm{H}_{32} \mathrm{~N}_{6} \mathrm{~S}_{2} \mathrm{Ni}_{2} \mathrm{Br}_{2} \cdot 3 \mathrm{CH}_{3} \mathrm{OH}$. $3 \mathrm{H}_{2} \mathrm{O}: \mathrm{C}, 42.37 ; \mathrm{H}, 5.08 ; \mathrm{N}, 8.47$. Found: C, 42.76; H, 5.13; N, 8.41. ESI-MS found (calcd): $[\mathrm{M}-2 \mathrm{Br}]^{2+} \mathrm{m} / z 340.0$ (340.04); $[\mathrm{M}-\mathrm{Br}]^{+}$ $\mathrm{m} / z 759.0$ (759.00).

\section{ASSOCIATED CONTENT}

\section{S Supporting Information}

The Supporting Information is available free of charge on the ACS Publications website at DOI: 10.1021/acs.organomet.7b00576.

Additional figures and tables as described in text (PDF)

\section{Accession Codes}

CCDC 1562886-1562889 contain the supplementary crystallographic data for this paper. These data can be obtained free of charge via www.ccdc.cam.ac.uk/data_request/cif, or by emailing data_request@ccdc.cam.ac.uk, or by contacting The Cambridge Crystallographic Data Centre, 12 Union Road, Cambridge CB2 1EZ, UK; fax: +44 1223336033.

\section{AUTHOR INFORMATION}

\section{Corresponding Author}

*E-mail: bouwman@chem.leidenuniv.

\section{ORCID}

Elisabeth Bouwman: 0000-0001-7762-3968

\section{Notes}

The authors declare no competing financial interest.

\section{ACKNOWLEDGMENTS}

S.L. gratefully acknowledges a grant from the Chinese Scholarship Council (No. 201306410011). We thank Dr. D.G.H. Hetterscheid for helpful discussions, and Mr. J.M.M. van Brussel for ESI-MS measurements.

\section{REFERENCES}

(1) Rausch, B.; Symes, M. D.; Chisholm, G.; Cronin, L. Science 2014, $345,1326-1330$.

(2) DuBois, D. L. Inorg. Chem. 2014, 53, 3935-3960.

(3) Simmons, T. R.; Berggren, G.; Bacchi, M.; Fontecave, M.; Artero, V. Coord. Chem. Rev. 2014, 270, 127-150.

(4) Tong, P.; Xie, W.; Yang, D.; Wang, B.; Ji, X.; Li, J.; Qu, J. Dalton Trans 2016, 45, 18559-18565.

(5) Canaguier, S.; Fourmond, V.; Perotto, C. U.; Fize, J.; Pecaut, J.; Fontecave, M.; Field, M. J.; Artero, V. Chem. Commun. 2013, 49, 5004-5006.

(6) Gan, L.; Groy, T. L.; Tarakeshwar, P.; Mazinani, S. K. S.; Shearer, J.; Mujica, V.; Jones, A. K. J. Am. Chem. Soc. 2015, 137, 1109-1115.

(7) Brazzolotto, D.; Gennari, M.; Queyriaux, N.; Simmons, T. R.; Pecaut, J.; Demeshko, S.; Meyer, F.; Orio, M.; Artero, V.; Duboc, C. Nat. Chem. 2016, 8, 1054-1060.

(8) Pandey, I. K.; Mobin, S. M.; Deibel, N.; Sarkar, B.; KaurGhumaan, S. Eur. J. Inorg. Chem. 2015, 2015, 2875-2882.

(9) Mondragón, A.; Flores-Alamo, M.; Martínez-Alanis, P. R.; Aullón, G.; Ugalde-Saldívar, V. M.; Castillo, I. Inorg. Chem. 2015, 54, 619-627.

(10) Hou, K.; Poh, H. T.; Fan, W. Y. Chem. Commun. 2014, 50, $6630-6632$.

(11) Song, L.-C.; Tan, H.; Luo, F.-X.; Wang, Y.-X.; Ma, Z.; Niu, Z. Organometallics 2014, 33, 5246-5253.

(12) Musina, E. I.; Khrizanforova, V. V.; Strelnik, I. D.; Valitov, M. I.; Spiridonova, Y. S.; Krivolapov, D. B.; Litvinov, I. A.; Kadirov, M. K.; Lonnecke, P.; Hey-Hawkins, E.; Budnikova, Y. H.; Karasik, A. A.; Sinyashin, O. G. Chem. - Eur. J. 2014, 20, 3169-82.

(13) Stolley, R. M.; Darmon, J. M.; Helm, M. L. Chem. Commun. 2014, 50, 3681-4.

(14) Helm, M. L.; Stewart, M. P.; Bullock, R. M.; DuBois, M. R.; DuBois, D. L. Science 2011, 333, 863-866.

(15) Morvan, D.; Capon, J.-F.; Gloaguen, F.; Le Goff, A.; Marchivie, M.; Michaud, F.; Schollhammer, P.; Talarmin, J.; Yaouanc, J.-J.; Pichon, R.; Kervarec, N. Organometallics 2007, 26, 2042-2052.

(16) McCrory, C. C.; Uyeda, C.; Peters, J. C. J. Am. Chem. Soc. 2012 134, 3164-70.

(17) Jacques, P. A.; Artero, V.; Pecaut, J.; Fontecave, M. Proc. Natl. Acad. Sci. U. S. A. 2009, 106, 20627-32.

(18) Kaeffer, N.; Morozan, A.; Artero, V. J. Phys. Chem. B 2015, 119, 13707-13.

(19) Laga, S. M.; Blakemore, J. D.; Henling, L. M.; Brunschwig, B. S.; Gray, H. B. Inorg. Chem. 2014, 53, 12668-12670.

(20) Tran, P. D.; Barber, J. Phys. Chem. Chem. Phys. 2012, 14, $13772-13784$.

(21) Kawano, K.; Yamauchi, K.; Sakai, K. Chem. Commun. 2014, 50, 9872-9875.

(22) van der Meer, M.; Glais, E.; Siewert, I.; Sarkar, B. Angew. Chem., Int. Ed. 2015, 54, 13792-5.

(23) Luo, S.; Siegler, M. A.; Bouwman, E. Eur. J. Inorg. Chem. 2016, 2016, 4693-4700.

(24) Jiang, S.; Zhang, T.; Zhang, X.; Zhang, G.; Hai, L.; Li, B. RSC Adv. 2016, 6, 84139-84148.

(25) Yuan, D.; Huynh, H. V. Organometallics 2010, 29, 6020-6027.

(26) Yuan, D.; Teng, Q.; Huynh, H. V. Organometallics 2014, 33, 1794-1800.

(27) Lal, A. K.; Milton, M. D. Tetrahedron Lett. 2014, 55, 18101814.

(28) Berding, J.; Lutz, M.; Spek, A. L.; Bouwman, E. Organometallics 2009, 28, 1845-1854.

(29) Berding, J.; van Dijkman, T. F.; Lutz, M.; Spek, A. L.; Bouwman, E. Dalton Trans 2009, 6948-6955.

(30) Reineke, M. H.; Sampson, M. D.; Rheingold, A. L.; Kubiak, C. P. Inorg. Chem. 2015, 54, 3211-3217.

(31) Yuan, D.; Huynh, H. V. Inorg. Chem. 2013, 52, 6627-6634.

(32) Jothibasu, R.; Huang, K.-W.; Huynh, H. V. Organometallics 2010, 29, 3746-3752.

(33) Kosterke, T.; Pape, T.; Hahn, F. E. Chem. Commun. 2011, 47, 10773-10775. 
(34) Huynh, H. V.; Jothibasu, R. Eur. J. Inorg. Chem. 2009, 2009, 1926-1931.

(35) Huynh, H. V.; Holtgrewe, C.; Pape, T.; Koh, L. L.; Hahn, E. Organometallics 2006, 25, 245-249.

(36) Bernhammer, J. C.; Huynh, H. V. Organometallics 2014, 33, $5845-5851$.

(37) Jenkins, R. M.; Singleton, M. L.; Leamer, L. A.; Reibenspies, J. H.; Darensbourg, M. Y. Inorg. Chem. 2010, 49, 5503-5514.

(38) Matson, E. M.; Espinosa Martinez, G.; Ibrahim, A. D.; Jackson, B. J.; Bertke, J. A.; Fout, A. R. Organometallics 2015, 34, 399-407.

(39) Brown, D. H.; Skelton, B. W. Dalton Trans. 2011, 40, 88498858.

(40) Martinez, G. E.; Ocampo, C.; Park, Y. J.; Fout, A. R. J. Am. Chem. Soc. 2016, 138, 4290-4293.

(41) Zhang, P.; Wang, M.; Yang, Y.; Yao, T.; Sun, L. Angew. Chem., Int. Ed. 2014, 53, 13803-13807.

(42) Stewart, M. P.; Ho, M.-H.; Wiese, S.; Lindstrom, M. L.; Thogerson, C. E.; Raugei, S.; Bullock, R. M.; Helm, M. L. J. Am. Chem. Soc. 2013, 135, 6033-6046.

(43) Tatematsu, R.; Inomata, T.; Ozawa, T.; Masuda, H. Angew. Chem., Int. Ed. 2016, 55, 5247-5250.

(44) Costentin, C.; Saveant, J.-M. ChemElectroChem 2014, 1, 12261236.

(45) Saveant, J. M. ChemElectroChem 2016, 3, 1967-1977.

(46) Wiedner, E. S.; Bullock, R. M. J. Am. Chem. Soc. 2016, 138, 8309-8318.

(47) Costentin, C.; Drouet, S.; Robert, M.; Savéant, J.-M. J. Am. Chem. Soc. 2012, 134, 11235-11242.

(48) Sheldrick, G. M. Acta Crystallogr., Sect. A: Found. Crystallogr. 2008, 64, 112-122.

(49) Dinda, J.; Adhikary, S. D.; Seth, S. K.; Mahapatra, A. New J. Chem. 2013, 37, 431-438. 